\title{
シールドトンネル縦断方向の現場載荷試験とその考察 \\ IN-SITU TESTS AND CONSIDERATION ON SHIELD TUNNEL IN THE LONGITUDINAL DIRECTION
}

\author{
西野健三*·吉田和夫**・小泉 淳*** \\ By Kenso NISHINO, Kazuo YOSHIDA and Atsushi KOIZUMI
}

\begin{abstract}
To evaluate the rigidity of a shield tunnel in the longitudinal direction, in-situ load tests were performed using the drive power of a shield machine and the dead weight of a battery locomotive.

It was shown that, if deformation characteristics of the segments ring joints were known, the behavior of the shield tunnel as a cylinder could be represented by a simple beam model on a elastic foundation.

We also discussed on the construction of sharply curved tunnels in the longitudinal direction, using the proposed analytical model.
\end{abstract}

Keywords: shield tunnel, in-situ test, segment, longitudinal direction

\section{1. まえがき}

シールド工法は，他工法と比べて地上施設に対する影 響が少ないことや, 既設構造物との関係で深いトンネル を掘る場合, 安全性や経済性に優れていることなどから， 都市トンネル構築方法として代表的な位置を占めてい る.この工法も近年の都市トンネル建設の急激な増加に 伴い, 軟弱地盤中や周辺地盤が急変する地山中での建設 をはじめとして, 急曲線施工や既設構造物に対する近接 施工など，ますます厳しい条件下での建設を余儀なくさ れている.これらの悪条件下のシールド工事では, トン ネルの一次覆工であるセグメントの設計も, トンネル横 断方向の設計だけでなく, 地盤沈下や曲線施工に対する 検討, さらには地震時の検討などトンネル縦断方向の安 全性の検討が不可欠な問題となってきている11,2).

地中構造物のうち, 埋設管路の場合には一般に,これ らの検討に際して, 管路をはり, 地盤を弾性ばねとした 弾性床上はりモデルが用いられているが, これをシール ドトンネルに適用する場合においては, 特にシールドト

* 正会員 工修 中部電力 (株)中央送変電建設所土木工事 課（４556 名古屋市熱田区横田 2-3-24）

** 中部電力 (株) 中央送変電建設所調查役 (同上)

*** 正会員 工博 東洋大学助教授 工学部土木工学科 （テ350 川越市鲸井中野台 2100）
ンネルをはりに置き換える際に, その剛性をどのように 評価するかが重要な問題となる. すなわち, シールドト ンネルは数多くの継手を有するため, これを弾性床上の はりとして取り扱う場合には, 継手部における剛性低下 を明確に把握することが必要不可欠であると考えられる からである。

シールドトンネルの縦断方向の剛性評価については, 従来ほとんど取り上げられなかったのが実状である.こ れは，シールドトンネルが長大な構造物であり，直接的 な試験を行うには，膨大な費用を要することや，無数に ある継手を解析上どのように取り扱えばよいかが明確で ないことによると思われる.したがって，シールドトン ネルの縦断方向の挙動に関する研究は, 文献 3), 4) に みられる程度にすぎない。

本研究は, まず, シールドトンネルの縦断方向の挙動 を実験的に把握する目的で, シールド機掘進推力（以下 推力とよぶ) や坑内作業車 (以下作業車とよぶ) などの 荷重を利用して，施工中のトンネルに対する現場載荷試 験を行い, 次に, これらの試験結果をもとに, シールド トンネルの簡単な解析モデルを提示するとともに，これ により得られた解析結果と試験結果とを比較し検討を加 えたものである. また, 本研究は得られたトンネル解析 モデルを用いて, 急曲線施工時の曲線内側の継手目開き 
問題など，施工時におけるトンネル綐断方向の検討方法 についても言及している.

\section{2. 現場載荷試験}

現場で行った試験は，トンネル直線部において推力を 利用して行った直線部推力試験, 作業車自重を利用して 行った鉛直載荷試験，およびトンネル曲線部で推力を利 用して行った曲線部推力試験の 3 種類である. 試験は, 2 加所の電力洞道建設工事 (A 工区，B 工区) において 実施した。 その概要を表一1に示す。これらのトンネル は，電力洞道としては標準的なサイズであり，使用した $\mathrm{RC}$ 平板型セグメントは，シールド工事用標準セグメン ト5)に準拠して設計したものである. なお，B工区のセ グメントのリング継手の数が，A工区のそれと比べて 多いのは, 軟弱地盤中での地震時の検討 ${ }^{6)}$ 之, 急曲線施 工の検討を行った結果である，RCセグメントのコンク リート配合は，両工区とも同じものを用いた．その配合 表を表一2に示す。

以下に，各試験の目的とその概要を示す.

\section{（1）直線部推力試験}

試験の概要を図一1 に示す。この試験は，トンネル直 線部において，トンネル縦断方向に圧縮力が作用した場 合の挙動を把握するためのものであり,これにより，地 盤の剛性すなわちトンネル縦断方向と平行する地盤反力 ばね定数（以下接線方向地盤反力ばね定数とよぶ）と， 圧縮力に対するトンネルの軸剛性を推定した。

\section{表一1 工事の概要}

\begin{tabular}{|c|c|c|c|}
\hline & AI区 & BI区 \\
\hline \multirow[t]{4}{*}{ シールド撒 } & 程 & 泥水加圧式 & 泥水加圧式 \\
\hline & 外 径 & $4.64 m$ & $4.64 \mathrm{~m}$ \\
\hline & 機 長 & $5.64 \mathrm{~m}$ & $5.48 \mathrm{~m}$ \\
\hline & 都推力 & $100 \times 18=1,800 \mathrm{tf}$ & $100^{\prime \prime} \times 18=1,800 \mathrm{tf}$ \\
\hline \multirow[t]{6}{*}{ セグメント } & 原 & $\mathrm{RC}$ 平板型 & RC平板型 \\
\hline & 外程 & $4.5 \mathrm{~m}$ & $4.5 \mathrm{~m}$ \\
\hline & 厚 & $0.2 \mathrm{~m}$ & $0.2 m$ \\
\hline & 幅 & $1.0 \mathrm{~m}$ & $1.0 \mathrm{~m}$ \\
\hline & 分 音 & 6分害 & 6分剖 \\
\hline & 䢽 手 & 16蔨 & 21蔨 \\
\hline \multirow[t]{3}{*}{ 地整 } & 土讙り & $14 m$ & $13 m$ \\
\hline & 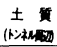 & 固蛣シルト & 眇質シルト \\
\hline & $\mathrm{N}$ 值 & $40 \sim 50$ & $5 \sim 10$ \\
\hline
\end{tabular}

表一2 セグメントのコンクリート配合表

\begin{tabular}{|c|c|c|c|c|c|c|c|c|}
\hline 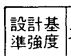 & & 空気量 & $w / c$ & $S / A$ & セxント & * & $s$ & \\
\hline & & & & & {$\left[\begin{array}{c}430 \\
{\left[\mathrm{~kg} / \mathrm{m}^{3}\right]}\end{array}\right]$} & 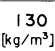 & $\begin{array}{l}775 \\
{\left[\mathrm{~kg} / \mathrm{m}^{3}\right]}\end{array}$ & S \\
\hline
\end{tabular}

測定は，セグメント本体中央部に設置した鉄筋計と， リング継手部に設置した $\pi$ 型継手変位計（以下継手変 位計とよぶ）により行った。なお，試験は，先に述べた A 工区，B 工区の 2 か所において同様に実施し，地盤 状況の相異による比較検討を行った，A工区および B 工区での土質概要を図一2に示す.

\section{（2）鉛直載荷試験}

試験の概要を図一3に示す。この試験はトンネル直線 部において鉛直荷重が作用した場合の挙動を把握するた めのものであり,これにより, 地盤の剛性すなわちトン ネル縦断方向に直交する地盤反力ば祮定数（以下法線方 向地盤反力ばね定数とよぶ）と，トンネルの曲げ剛性を 推定した。

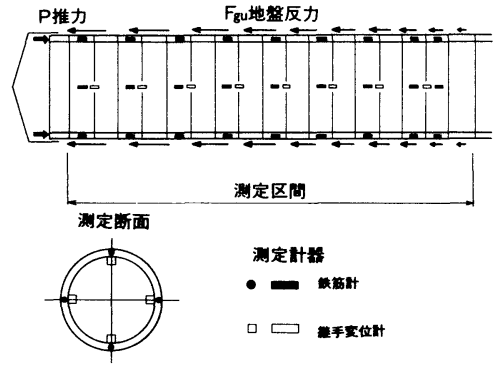

図一1 直線部推力試験の概要
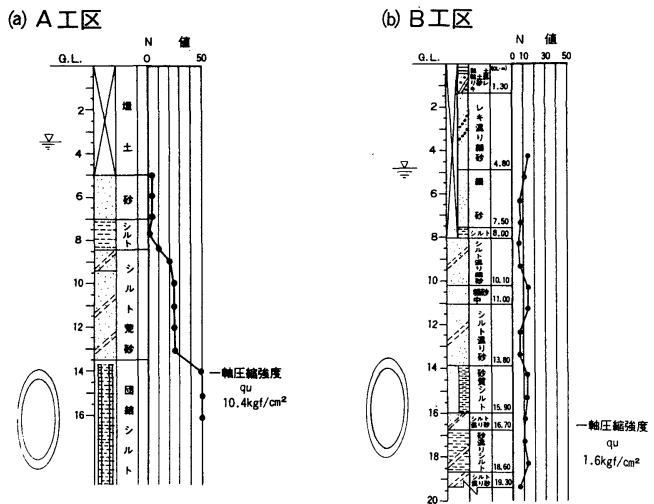

図一2 土質柱状図
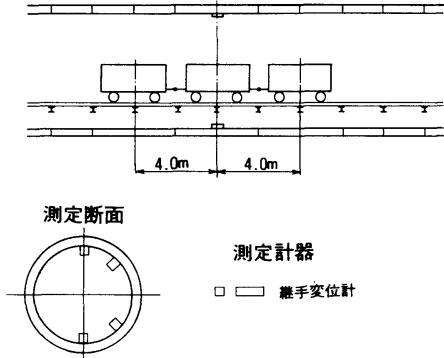

図一３鉛直载荷試験の概要 


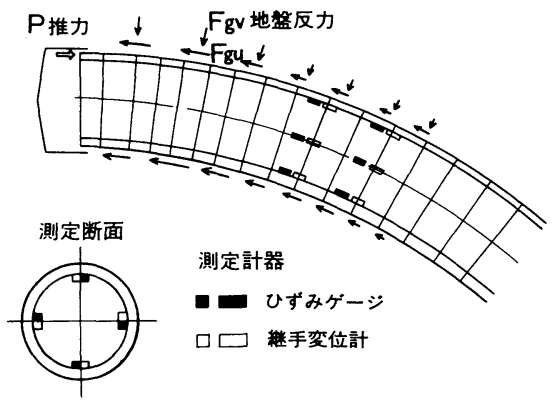

図一4 曲線部推力試験の概要
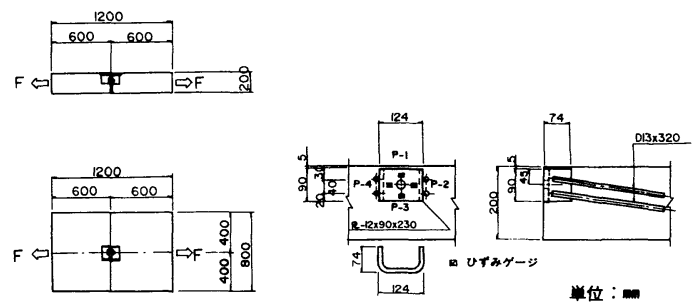

位: $\mathrm{mm}$

図一5 リング継手部引 張り試験の概要

測定は,リング継手部に設置した継手変位計により行 い,リング継手部の伸縮量を計測した。なおここの試験 も直線部推力試験と同じ位置で, 両工区同様に実施し, 比較検討を行った。

\section{(3) 曲線部推力試験}

試験の概要を図一4に示す。この試験はトンネル曲線 部において圧縮力および曲げモーメントが作用した場合 の挙動を把握するためのものであり，これにより，地盤 の剛性と, 圧縮力と曲げモーメントを受ける場合のトン ネルの剛性を検討した.

測定は，セグメント本体内面に貼付したひずみゲージ と, リング継手部に設置した継手変位計により行った. なお，この試験は，B工区のみにおいて実施し，場所

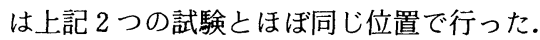

以上の現場での各試験のほかに，室内において，実物 大のリング継手部引張り試験 (図一5 参照)など7)を行い, トンネルの剛性を推定する際の参考とした.なお，すべ ての試験に用いたセグメントのリング継手部の詳細は, 図一6に示すとおりである.ボルトは，M 22 (8.8) を 用い, その締め付けトルクは，30 kgfm $(294 \mathrm{Nm})$ とな るようにトルクレンチを用いて管理した.

\section{3. 直線部推力試験の結果とその解析 ${ }^{8)}$}

\section{（1）試験結果と考察}

両工区ともシールド機には, $100 \mathrm{tf}(980 \mathrm{kN})$ の推力 ジャッキを 18 本装備してあったが, 載荷に際しては,
全ジャッキを使用し，均等に作用するように注意を払つ た. 平均推力は A 工区で $780 \mathrm{tf}(7640 \mathrm{kN})$, B 工区で $700 \mathrm{tf}(6860 \mathrm{kN})$ であり, 以下の測定値は,この平均 推力に換算した值としてまとめた.

図一7は，推進時のセグメント本体のひずみ分布を示 したものである. 横軸には, 推力が作用している地点と 各測定計器との距離を示した。なお，図中の丸印は試験

(a) A I区

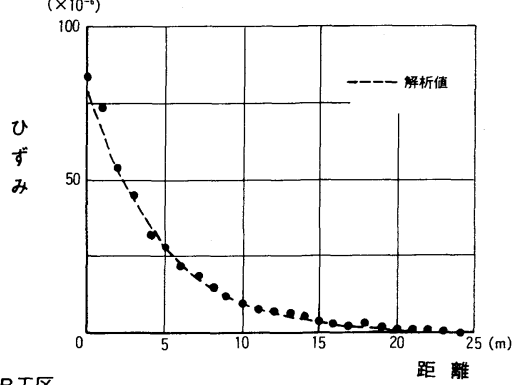

(b) BI区

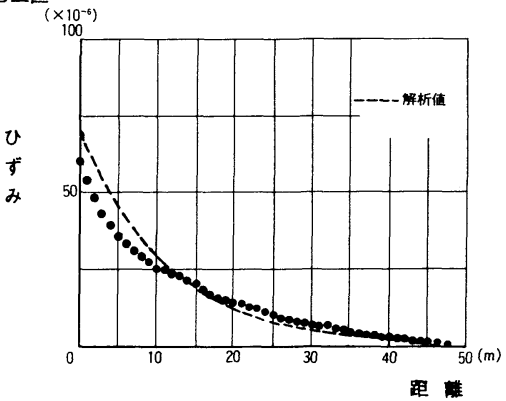

図一7 セグメント本体のひずみ分布（直線部推力試験）

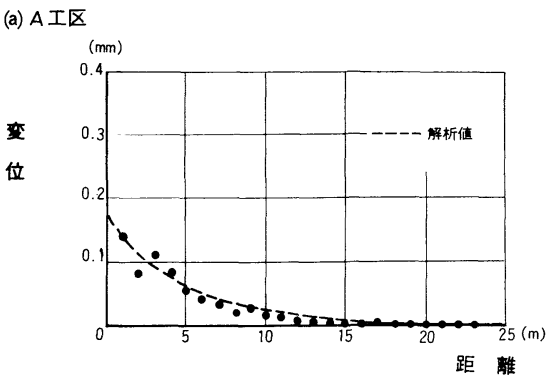

(b) BI区

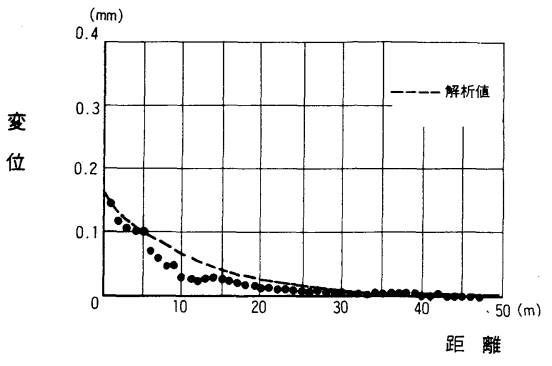

図一8 リング継手部の变位分布（直線部推力試験） 
結果を,また, 破線は後で述べる解析モデルを用いて行っ た解析結果を，それぞれ示したものである．地盤反力に よる推力の減衰状況がはっきりと現われているが，減衰 は地盤の硬い A 工区の方が著しい，A 工区では，ジャッ キが直接作用しているリングより約 $25 \mathrm{~m}$ 後部で推力の 影響がほぼなくなっているのに対し，B工区では，そ の 2 倍の地点まで影響が及んでいることがわかる。

図一8 は, 推進時のリング継手部の変位分布を示した ものである. セグメント本体のひずみ分布に比べ，その 影響範囲は比較的小さいが，これも軟らかい地盤の方が より後部へ影響が及んでいることがわかる。なお，これ らの図中の点は, 測定断面についての各計器の平均值を 示したものである.

図一 9 は，図一7 と図一8 とを用い，それぞれ $25 \mathrm{~m}$ 後 部と $50 \mathrm{~m}$ 後部を不動点と仮定し, セグメント本体のひ ずみから求めたセグメント本体の縮み量と継手部の変位 量を累積して求めたトンネルと地盤との相対変位の分布 を示したものである．試験值をみる亡相対変位の減衰状 況は，比較的なめらかなものとなっているものの，地盤 の硬い A 工区の方が急激な減衰を示しているのがわか る. A 工区では，ジャッキが直接作用しているリング より約 $5 \mathrm{~m}$ 後部で相対変位がほぼ半減しているのに対 し, B 工区では, 約 $10 \mathrm{~m}$ 後部でほぼ半減している.

次に，これらの分布図より，地盤の剛性とリング継手 部の剛性を推定してみた．図一10は，図一7と図一9よ り求めた地盤反力と相対変位との関係を示したものであ る. 地盤反力は，図一7におけるセグメント本体のひず み分布の差分量にセグメントの弾性係数とトンネル断面 積を乗じて求めた．なお, セグメントの弾性係数は, 静

(a) A I区

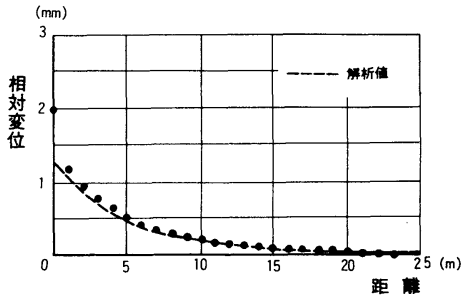

(b) BI区

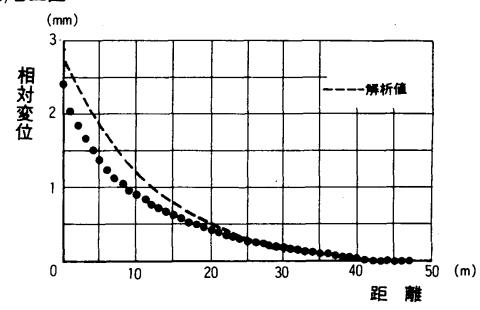

図一- トンネルと地盤との相対变位分布
弾性係数試験結果より求めた $E=3.7 \times 10^{5} \mathrm{kgf} / \mathrm{cm}^{2}(36$ $\mathrm{GPa}$ ）を用いた．図一10をみると地盤反力は，相対変 位に比例し，地盤の抵抗をトンネル縦断方向に平行な地 盤反力ばねとして評価することの妥当性が示されてい る.なお，その勾配から与えられる地盤反力ばね定数は, セグメント外面の単位面積当たり，A 工区で $\mathrm{kgu}=9.0$ $\mathrm{kgf} / \mathrm{cm}^{3}\left(88 \mathrm{MN} / \mathrm{m}^{3}\right)$, B 工区で $\mathrm{kgu}=1.5 \mathrm{kgf} / \mathrm{cm}^{3}(15$ $\left.\mathrm{MN} / \mathrm{m}^{3}\right)$ となった。

図一11は，図一7 と図一8より求めたりング継手部に 作用する圧縮力と変位との関係を示したものである. 図 一11をみるとリング継手部の挙動も，ほぼ弾性的なば ねとして評価できることがわかる．この勾配より与えら れるリング継手部のばね定数は, 両工区ともほぼ同じ値 で $K_{r c}=4.5 \times 10^{7} \mathrm{kgf} / \mathrm{cm}(44 \mathrm{GN} / \mathrm{m})$ となった．圧縮 力に対するリング継手面の剛性を考えると，理論的には トンネル横断面の断面積は，ほぼ全断面有効とみなして よいと思われるが，実際には，コンクリートや継手金具 などリング継手面における製作精度，リング継手部の断 面欠損，セグメントの組み立て精度，シール材のはみ出 しなごの影響を受けて, リング継手面の剛性はかなり低 下していることが予想される.なお,当工事に用いたシー ル材は, セグメントのシール溝内に $100 \%$ おさまるシー ル材を用いているため，これによる影響はあまりないと 考えられる. また，参考までに，水中養生下での裏込め 注入材強度試験結果を図一 12 に示す。約 $1 / 4$ 日で周辺 地盤と同程度の強度に達している。この間におけるシー
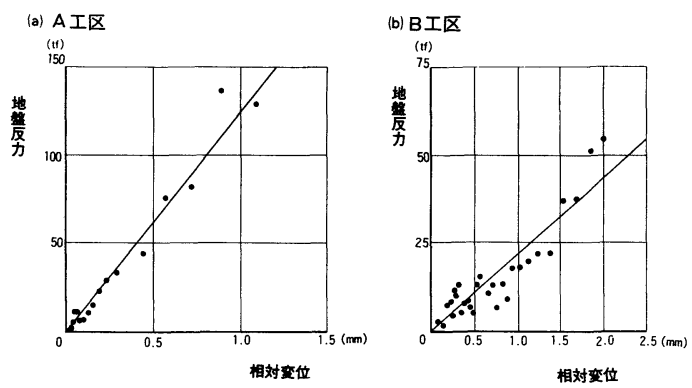

図一10地盤反力と相対变位
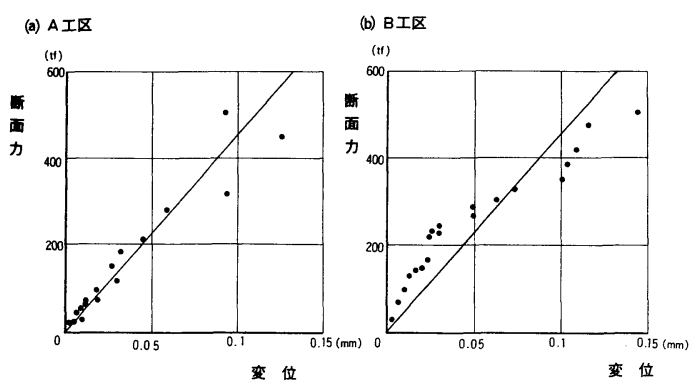

図一11 リング継手部の断面力と変位 


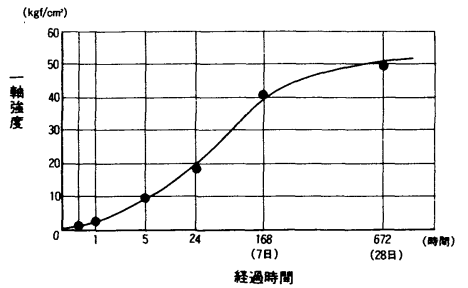

図一12 裏込め注入材の強度

ルド掘進は 2 4 m であり, 推力作用部付近の数リング を除いて, 裏込め注入材の強度不足による影響はほぼな いと考えられる.

（2）解 析

a) 構造解析モデル

図一13 は, 直線部推力試験に対する構造解析モデル を示したものである.トンネルは剛性一様なはりに，ま た，地盤は弾性ばねにそれぞれ評価した。図中の $P_{J}$ は 推力, $(E A)_{e q}$ はトンネルの等価軸剛性, $K_{g u}$ は接線方 向地盤反力ばね定数をそれぞれ表わしている.

圧縮力に対するトンネルの等価軸剛性は, セグメント 本体の軸剛性 $E A$ と, 試験より得られたリング継手部 の圧縮力に対するばね定数 $K_{r c}$ を用いて, 式 (1) およ び ( 2 ) から求めた (図一14 参照).

$(E A)_{e q}=\alpha_{c} E A$

$$
\alpha_{c}=\frac{K_{r c}}{K_{r c}+E A / l_{s}}
$$

式中の $l_{s}$ は，セグメント幅を表わし， $\alpha_{c}$ は，トンネル 本体の軸剛性の有効率を表わしている. なお, 得られた 結果からリング継手部の変位を求めるには, 式 $(3)$ を 用いればよい。

$$
F_{r c}=K_{r c} \delta_{r}
$$

式中の $F_{r c}$ はリング継手部に作用する王縮力， $\delta_{r}$ は リング継手部の変位をそれぞれ表わしている.

本試験の結果得られた圧縮力に対するトンネルの軸剛 性の有効率は, $\alpha_{c}=0.3$ 程度であった。

b) 試験結果と解析結果との比較

以上に述べた解析モデルを用いて解析を行った結果を 図一7〜9中に破線で示す. 解析結果は試験結果をよく

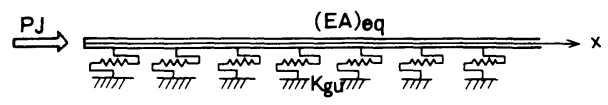

図一13構造解析モデル（直線部推力試験）

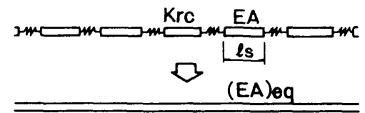

図一14 等価軸剛性の設定
説明しており，この解析モデルの妥当性が示された.

なお，解析に際して荷重は，平均推力を用い，また， 地盤反力ばねおよびリング継手部のばねのばね定数はそ れぞれ試験より求めた值を用いている.

\section{4. 鉛直載荷試験の結果とその解析}

\section{(1) 試験結果と考察}

作業車は, 両工区とも 3 台使用し, その自重は, $\mathrm{A}$ 工区では 3 台とも $6 \mathrm{tf}(59 \mathrm{kN}), \mathrm{B}$ 工区では中央の 1 台 が $6 \mathrm{tf}(59 \mathrm{kN})$ 両側 2 台が $4 \mathrm{tf}(39 \mathrm{kN})$ である.

図一15 は, A工区において, トンネル断面のクラウ ン位置とインバート位置でのリング継手部の変位分布を 示したものである，横軸は，測定断面と中央の作業車の 中心との距離を示し, 縦軸の変位は, 圧縮方向を正, 引 張り方向を負として示した. 同様に，B工区における 試験結果を図一16に示す.

リング継手部の最大変位は, B I区でのものが A I 区でのものの約 7 倍程度であった。これは, 地盤の軟ら かいB工区において, 荷重が小さいうえに, 継手個数

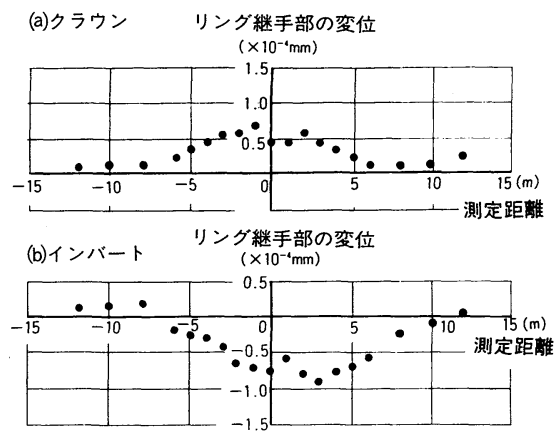

図一15 リング継手部の变位分布 (鉛直載荷試験, A 工区)

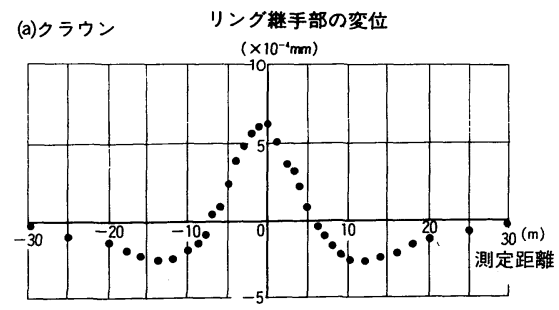

(b)インバート リング継手部の変位

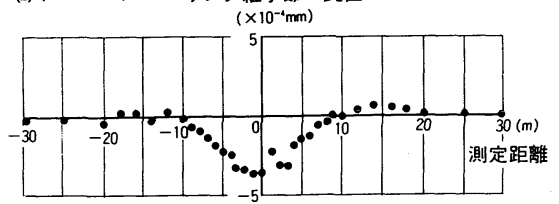

図一16 リング継手部の変位分布（鉛直載荷試験，B工区） 
が多いにもかかわらず，トンネルの変形がかなり大きい ことを示している. また, 地盤の軟らかい B 工区では, その変形の影響が地盤の硬い A 工区に比べ， 3 倍程度 にも及んでいる.

一方, リング継手部の変位分布形状をみると, B工 区でのものが $10 \mathrm{~m}$ 付近において大きく変曲し, $0 \mathrm{~m}$ 付 近における変位と逆方向に変位しているのがわかる。こ れに対し，A工区では，ほとんゼ一方向のみで，比較 的単調な分布となっている.これは，A工区においては， 地盤が硬いため，地盤がよく荷重を支えており，B工 区においては，地盤が軟らかいために，トンネルの方が 荷重を支える傾向にあるためと考えられる.

\section{（2）解 析}

a) 構造解析モデル

図一17 は，鈶直載荷試験に対する構造解析モデルを 示したものである. 直線部推力試験に対する解析モデル 同様，トンネルは剛性一様なはりに，また，周辺の地盤 は弾性ばねにモデル化した。図中の $P_{v}$ は鉛直荷重すな わち作業車の自重, $(E I)_{e q}$ はトンネルの等価曲げ剛性, $K_{g v}$ は法線方向地盤反力ばね定数をそれぞれ表わしてい る. トンネルの等価曲げ剛性は，セグメント本体の曲げ 剛性 $E I$ とリング継手部の回転ばね定数 $K_{r \theta}$ から式 (4) および式（5）を用いて算出した(図一18参照).

$$
(E I)_{e q}=\beta E I
$$

$$
\beta=\frac{K_{r \theta}}{K_{r \theta}+E I / l_{s}}
$$

式中の $l_{s}$ は，セグメント幅を表わし， $\beta$ は，トンネル 本体の曲げ剛性の有効率を表わしている. なお, 得られ た結果からリング継手部の回転角を求めるには, 式 (6) を用いればよい。

$$
M_{r}=K_{r \theta} \theta_{r}
$$

式中の $M_{r}$ はリング継手部に作用する曲げモーメント， $\theta_{r}$ はリング継手部の回転角をそれぞれ表わしている.

本試験の結果および次に述べるリング継手部の回転ば ね定数より, トンネルの曲げ剛性の有効率は, $\beta=0.2$

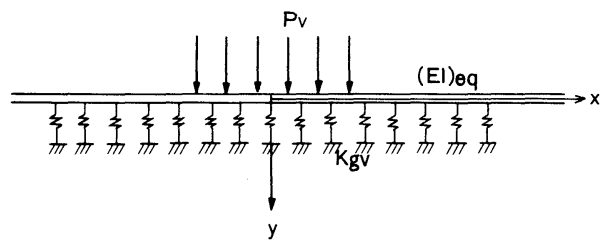

図一17 構造解析モデル（鉛直載荷試験）

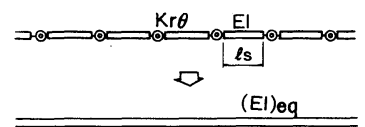

図一18 等価曲げ剛性の設定

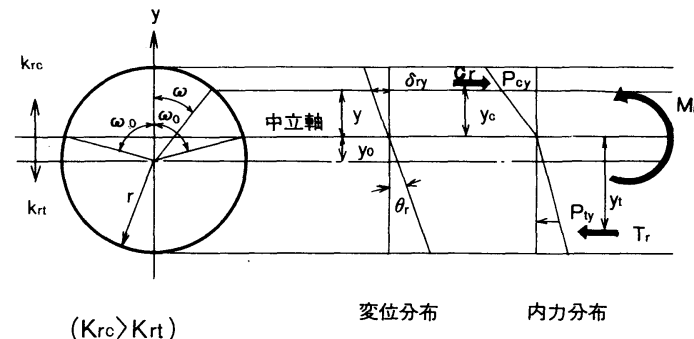

図一19 リング継手部のモデル化

程度であった。

b）リング継手部の回転ばね定数

リング継手部の回転ばね定数を求めるにあたり，曲げ モーメントが作用するリング継手部に，以下の仮定を設 ける.

(1) 図一19に示すように，リング継手部のばねは, セグメントリングの図心半径 $r$ で示される円周上 に，一様に分布する。

(2) 断面の中立軸を挟んで，上側は圧縮ばね，下側は 引張りばねとする。

なお，図一19中の $k_{r c}$ および $k_{r t}$ は，単位周長当たりの 圧縮力および引張り力に対するばね定数をそれぞれ表わ しており，その值は，式（7）および式（8）で与えら れる.

$$
\begin{aligned}
& k_{r c}=\frac{K_{r c}}{2 \pi r} \cdots \ldots \ldots . . . \\
& k_{r t}=\frac{K_{r t}}{2 \pi r}=\frac{n k_{t}}{2 \pi r}
\end{aligned}
$$

式中の $K_{r t}$ は, リング継手部の引張り力に対するばね定 数であり, $n$ はリング継手の個数, $k_{t}$ はリング継手 1 個当たりの引張り力に対するば站定数 ${ }^{9)}$ である。 また， 図一19中の断面力 $P_{c y}, P_{t y}$ は式 $(9) ，(10)$ より求め られる。

$$
\begin{aligned}
& P_{c y}=k_{r c} \delta_{r y} \doteqdot k_{r c} r\left(\cos \omega-\cos \omega_{0}\right) \theta_{r} \\
& P_{t y}=k_{r t} \delta_{r y} \doteqdot k_{r t} r\left(\cos \omega-\cos \omega_{0}\right) \theta_{r}
\end{aligned}
$$

これらの合力 $C_{r}, T_{r}$ は式 (11)，(12) で与えられる が，この $2 つ の$ 合力のつり合い式 (13) より，図一19 中の断面中立軸位置を示す $\omega_{0}$ は式 (14) で与えられる.

$$
\begin{aligned}
& C_{r}=2 \int_{0}^{\omega_{0}} P_{c y} r d \omega . \\
& T_{r}=2 \int_{\omega_{0}}^{\pi} P_{t y} r d \omega . \\
& C_{r}+T_{r}=0 \ldots \ldots \ldots \ldots .
\end{aligned}
$$

$$
\tan \omega_{0}=\omega_{0}+\frac{k_{r t}}{k_{r c}-k_{r t}} \pi
$$

さらに，モーメントのつり合い式（15）を用いること により,リング継手部の回転ばね定数は式（16）で与え られる. 

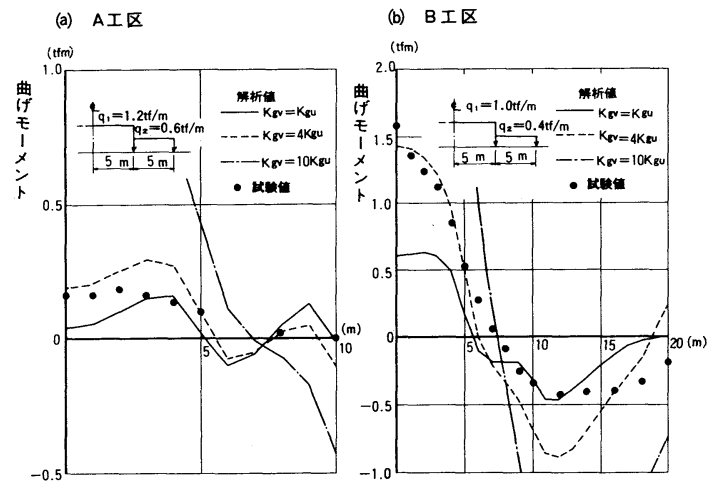

図一20 曲げモーメント分布（鉛直載荷試験）

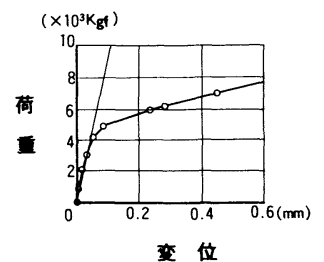

図一21 リング継手部引張り試験の結果

$$
\begin{aligned}
M_{r}= & C_{r} \cdot y_{c}+T_{r} \cdot y_{t} \cdots \cdots \cdots \cdots \cdots \cdots \cdots \cdots \cdots \cdots \cdots \cdots \cdots \cdots \\
K_{r \theta}= & 2 r^{3}\left[( k _ { r c } - k _ { r t } ) \left\{\left(\frac{\cos 2 \omega_{0}}{2}+1\right) \omega_{0}\right.\right. \\
& \left.\left.-\frac{3}{4} \sin 2 \omega_{0}\right\}+k_{r t}\left(\frac{\cos 2 \omega_{0}}{2}+1\right) \pi\right] .
\end{aligned}
$$

c) 試験結果と解析結果との比較

図一20は，以上に述べた解析モデルを用いて求めた 解析結果と，試験結果とを比較したものである．荷重は 図一20中に示すように，まくらぎやセグメントの剛性 などによる荷重分散を考慮し，等分布荷重に換算して， 解析を行った ${ }^{10)}$. また, リング継手の 1 個当たりの引張 りカに対するばね定数は, 別途実施したリング継手部引 張り試験結果（図一21参照）を用いて, $k_{t}=1.0 \times 10^{6}$ $\mathrm{kgf} / \mathrm{cm}(980 \mathrm{MN} / \mathrm{m})$ とした. なお, 図一20中の試験 值は, 図一15,16より得られるリング継手部の回転角 $\theta_{r}$ に式 (16) で得られる回転ばね定数 $K_{r \theta}$ を乗じて求 めた.

図一20をみると, 解析結果は試験結果をおおむね説 明しており, モデル化の妥当性が示された。なお, 今回 の場合には, 法線方向の地盤反力ばね定数は, 接線方向 のものの 4 倍程度が現状をよく説明できるようである.

\section{5. 曲線部推力試験の結果とその解析}

\section{（1）試験結果と考察}

曲線部推力試験は, 曲率半径 $150 \mathrm{~m}$, 曲線弧長 $50 \mathrm{~m}$ の区間を用いて行った。この曲線部の施工に際しては,

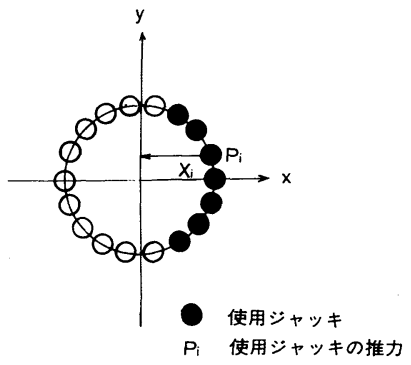

図一22 曲線施工の使用ジャッキ
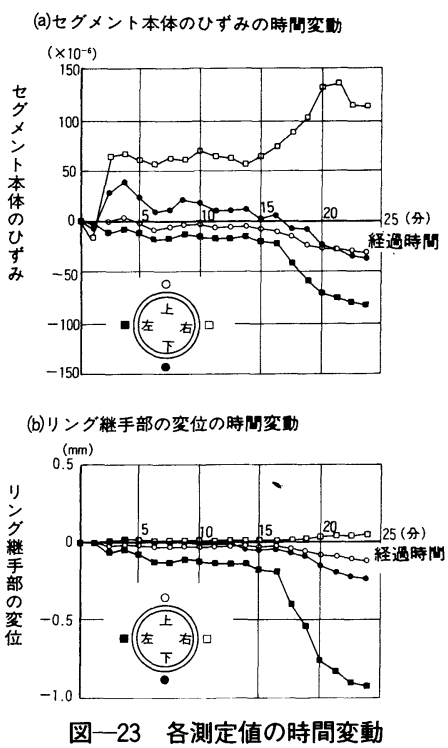

18 本のジャッキのうち, 図一22に示すように，ほぼ半 数を用いた. その平均推力は $P_{J}=500 \mathrm{tf}(4900 \mathrm{kN})$ で ある.また，図一22を参照して，これらのジャッキ推 力の偏心により生ずるモーメント $M_{J}$ は, 式 (17) で与 えられる.

$$
M_{J}=\sum P_{i} x_{i}
$$

今回の場合には, 平均で $M_{J}=200 \mathrm{tfm}(1960 \mathrm{kNm})$ であつ た。

図一23 は, 推力作用点より $5 \mathrm{~m}$ 後方の測定断面にお けるシールド推進中の各測定值の時間的変化を示したも のである.なお, シールド推進は 1 リング分, $1 \mathrm{~m}$ であ り，その間の推進速度はほぼ一定であった。 セグメント 本体のひずみとリング継手部の変位の両方とも, 推進前 半の変動の小さな部分と, 推進後半の変動の大きな部分 から成っている．この傾向は，測定断面との距離に関係 なく，ほとんど全部の測定結果に現われている.シール ド機とセグメントとのクリアランスやジャッキストロー クなどの挙動をみると,曲線部を施工中のシールド機は， 推進後半に所定の方向転換を生じるようで，これがセグ 
(a)セグメント本体のひずみ分布

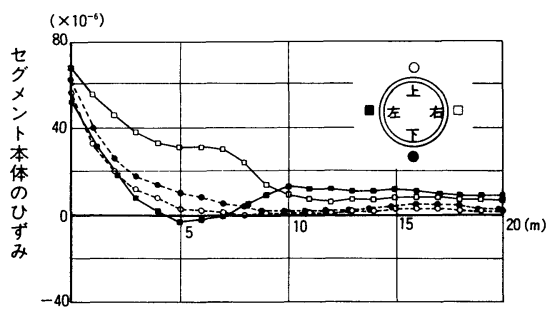

(b)リング継手部の変位分布

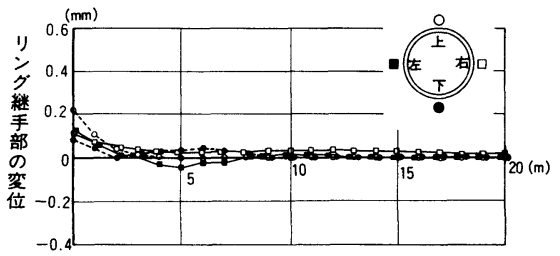

図一24 セグメント本体のひずみとリング継手部の変位の分布 (曲線部推力試験, 推進前半)

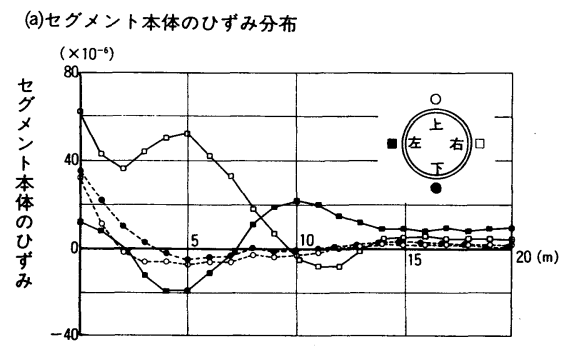

(b)リング継手部の変位分布

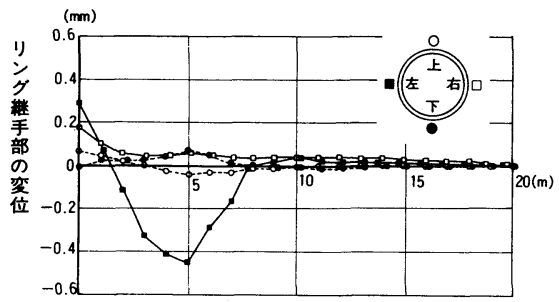

図一25 セグメント本体のひずみとリング継手部の変位の分布 (曲線部推力試験, 推進後半)

メント本体のひずみや継手部の変位を推進後半に変動さ せる原因と考えられる。

なお，図中のセグメント本体のひずみ，リング継手部 の変位の両方とも, 圧縮方向を正, 引張り方向を負とし ている.

図一24は, 変動の小さい推進前半における, セグメ ント本体のひずみとリング継手部の変位の分布を示した もので, 横軸は, 測定断面と推力作用点との距離を表わ している.これに対し, 図一25は, 変動の大きな推進 後半部分の同様な分布を示したものである.推進前半は, 単調な减衰傾向を示しているのに対し, 推進後半は, 推 力作用点から約 $5 \mathrm{~m}$ 後部付近にピークをもつやや複雑

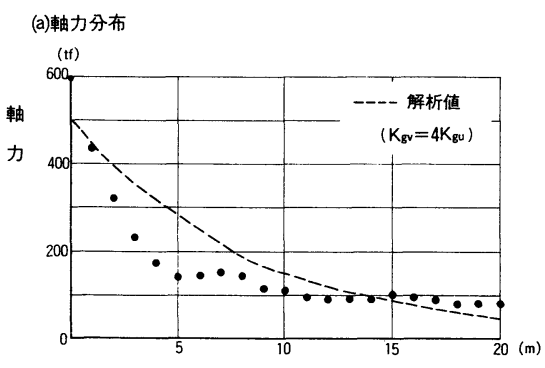

(b)曲げモーメント分布

測定距事

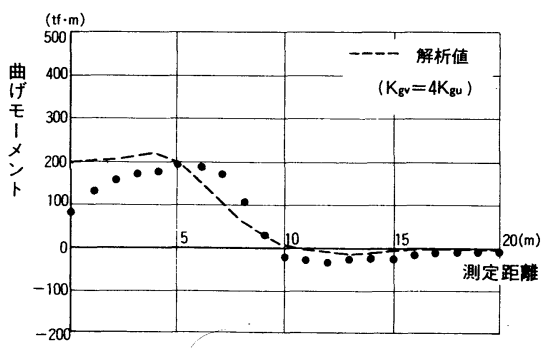

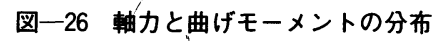
(曲線部推力試験, 推進前半)
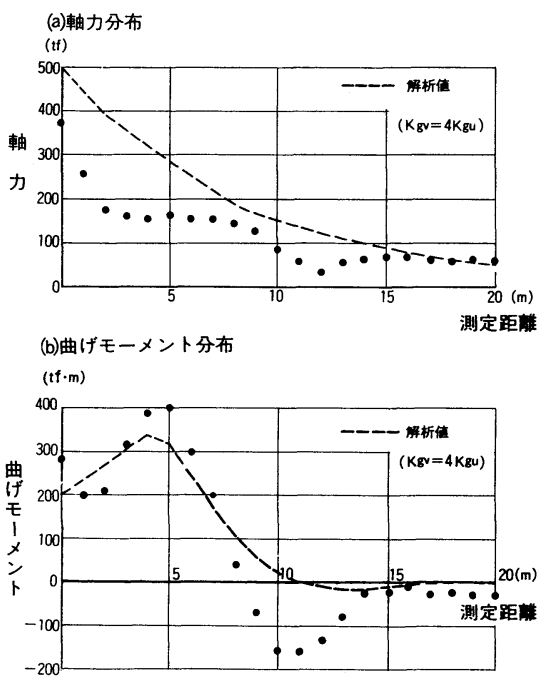

図一27軸力と曲げモーメントの分布 (曲線部推力試験, 推進後半)

\section{な減衰を示している.}

図一26は，推進前半におけるセグメント本体のひず みから, 以下の仮定に基づいて算出したトンネル縦断方 向の軸力と曲げモーメントの分布を示したものである.

(1) セグメント本体に引張りひびわれが発生せず，か つ, 引張りに対する弾性係数は，王縮に対するものと同 じ値である.

(2) セグメントリングは, 一様な円管断面である. 軸力は, 推力作用点付近でかなり大きな值を示すもの 

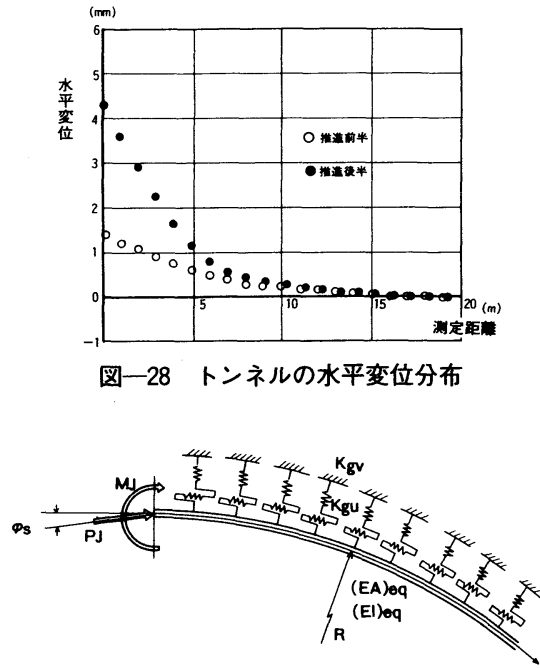

図一29構造解析モデル（曲線部推力試験）

の急激に減少し, 直線部推力試験の結果（図一7参照） とほぼ同じような傾向を示している.一方曲げモーメン 卜は, 後方 $5 \mathrm{~m}$ 付近までは増加し, 最大 $200 \mathrm{tfm}$ (1960 $\mathrm{kNm})$ まで達してから減少している.

図一27 は, 推進後半におけるセグメント本体のひず みから, 同様に算出した軸力と曲げモーメントの分布を 示したもので, 推進前半に比べ軸力が小さく，曲げモ一 メントが卓越していることがわかる. 特に後方 $5 \mathrm{~m}$ 付 近で約 $400 \mathrm{tfm}(3920 \mathrm{kNm})$ に達した後, 後方 $10 \mathrm{~m}$ 付 近では逆に-160 tfm $(-1570 \mathrm{kNm})$ 程度の負曲げが発 生しているのが特徴的である.

図一28 は，図一24 および図一25に示した継手部の変 位を累積して求めたトンネル水平方向の変位分布を示し たものである. 変動の大きい推進後半では, 推力作用点 において，トンネルが約 $4 \mathrm{~mm}$ 程度移動していることが わかる.

曲線施工時の偏心荷重によりトンネルに生じる曲げ モーメントは，七グメント本体のひびわれおよびリング 継手部の目開きなど，セグメントの覆工部材としての機 能を低下させることにもなるため, 注意を要する事項で ある．特に， RC七グメントでは，ボルトの破断や継手 板の降伏のおそれがあり問題となる一方，スチールセグ メントでは, 縦リブが座屈することも考えられ, 継手部 の設計に際して十分な検討が必要である.

\section{（2）解 析}

a) 構造解析モデル

図一29 は, 曲線部推力試験に対する構造解析モデル を示したものである. 図中の $\varphi_{s}$ は，トンネル線形に対 する推力の作用角度であり, シールド推進中に, シール ド機が急激な方向の転換をするために生じるもので，今
回のシールド機の場合ではテールクリアランスなどよ り，最大值が約 3 度程度と考えられる。

b) 試験結果と解析結果との比較

図一29に示した解析モデルを用いて解析した結果を 図一26，27 中に破線で示す。解析に用いたトンネルの 剛性および地盤反力ばね定数は，前述した B 工区にお ける $2 つ$ つ試験で得られた值と同じ値とした．なお，法 線方向地盤反力ばね定数については，水平方向と鉛直方 向が等しいと仮定し, また, 推力の作用角度は, 推進前 半で $\varphi_{s}=0$ 度, 推進後半で $\varphi_{s}=3$ 度と仮定した.

軸力では試験值が解析値を下回り, 曲げモーメントで は試験値が解析値を上回る傾向にあるが，解析結果は試 験値をおおむね説明している．現場における各種の不確 定要素を考虑すれば，実際の設計を行ううえでここで示 す解析モデルは，ほぼ妥当であるといえる.

\section{6. ま と め}

本研究で得られた結果をまとめると次のとおりであ る.

\section{（1）直線部推力試験}

(1) セグメント本体およびリング継手部に推力の影響 が及ぶ範囲は土質条件によって大きく異なり，今回 の場合硬質地盤で $25 \mathrm{~m}$, 軟弱地盤で $50 \mathrm{~m}$ 程度で あった。

(2) 圧縮力に対するトンネルの軸剛性は,リング継手 部の存在により，継手をもたないソリッドな場合に 比べかなり低下し，その有効率はおおむね $30 \%$ 程 度であった。

(3) 推力に対するシールドトンネルの挙動は, リング 継手部の変形特性を考慮に入れれば，簡単な弾性床 上はりモデルでよく説明できる.

\section{（2）鉛直載荷試験}

(1) 鉛直荷重により生ずるリング継手部の変位は, 土 質条件によって大きく異なり，軟弱地盤では硬質地 盤での値の 7 倍程度であった。

(2) 曲げモーメントに対するトンネルの曲げ用性は, リング継手部の存在により，継手をもたないソリッ ドな場合に比べかなり低下し，その有効率はおおむ ね $20 \%$ であった。

（3) 鉛直荷重に対するシールドトンネルの挙動は, リ ング継手部の変形特性を考慮に入れれば，簡単な弾 性床上はりモデルでよく説明できる。

\section{（3）曲線部推力試験}

(1) 曲線施工時に生じるセグメント本体のひずみおよ びリング継手部の変位は, 推力の大きさ, 作用角度 および地盤の剛性に影響を受ける。

(2) 推力の作用角度は，現場でのシールド機の実測な 
よ゙より 0〜3 度程度を考えるべきである.

(3) 曲げモーメントと軸力が同時に作用する場合でも リング継手部の変形特性を考虑に入れれば，シール ドトンネルの挙動は簡単な弾性床上はりモデルでお おむね説明できる.

\section{7. あとがき}

$\mathrm{RC}$ セグメントを用いたシールドトンネルの現場載荷 試験結果とその考察について報告した. 今回解析に用い た各種の定数は, 試験結果に基づくものがほとんどで あったが，シールドトンネルの縦断方向の検討を行う場 合に，リング継手の変形特性が明らかになれば，シール ドトンネルの挙動は, 基本的には簡単な弾性床上のはり で説明できることがわかった.したがって今後はこれら 各種の定数の合理的な推定方法を明らかにするととも に, 今回得られた構造解析モデルを用いて, 地震時およ び地盤沈下などの検討を行っていきたいと考えている. なお, 現在セグメント模型を用いて, 各種試験を行って おり，トンネルの剛性のより詳細な評価方法を検討中で ある。

最後に，この報告をまとめるにあたって，貴重なご意 見をいただいた早稻田大学理工学部 村上博智教授, 電 力中央研究所土木研究所 岩楯敞広博士, 同担当研究員 当麻純一氏, また, 現場計測にあたって多大なご協力を
いただいた日本シールドエンジニアリング(株) 加藤教 吉氏ほか，関係各位に深く感謝する次第である．

\section{参 考 文 献}

1）土木学会：トンネル標準示方書 (シールド編)，1977.

2）日本鉄道施設協会：シールドトンネルの設計施工指針 (案), 1977.

3）鳥取孝雄：シールドトンネルの軸方向変形に関する実験, 第 27 回土木学会年次学術講演会概要集, III-144, 1972.

4）小泉 淳・小柳隆司・村上博智：シールドトンネル長手 方向の変形挙動について, 第 34 回土木学会年次学術講演 会概要集, III-263, 1979.

5）土木学会, 日本下水道協会 : シールド工事用標準セグメ ント, 1982.

6）藍田正和・西野健三・田中 弘：セグメント継手部の剛 性を考慮した耐震設計について, 第 19 回土質工学研究発 表会概要集, H-5, 1984.

7）西野健三・近藤寛通・吉田和夫：RC セグメント継手部 の構造モデル化に関する試験とその考察, 構造工学論文 集, Vol. 31 A, 1985.

8）西野健三・加藤教吉：RC セグメントの推力伝播計測と その考察, 第 40 回土木学会年次学術講演会概要集, III $-164,1985$.

9）村上博智・小泉 淳：シールド工事用セグメントのセグ メント継手の挙動について, 土木学会論文報告集, 第 296 号, 1980.

10）土木学会：構造力学公式集, 1974.

(1986.3.28 • 受付) 